\title{
The Need for Inclusion of Geomatics Engineering as a Programme in Nigerian Universities and Registrable by Council for the Regulation of Engineering in Nigeria (COREN)
}

\author{
Okonofua E. S. ${ }^{1}$, Oladosu O. S. ${ }^{1}$ and Ehigiator -Irughe R. ${ }^{1 *}$ \\ ${ }^{1}$ Department of Geomatics, Faculty of Environmental Sciences, University of Benin, Benin City, Nigeria \\ Corresponding Author: *raphael.ehigiator@uniben.edu
}

\begin{abstract}
This paper presents the field of Geomatics as an evolving field, its relevance to other fields of engineering in general as well as other countries who have been practicing it. The rationale for teaching Geomatics Engineering courses in Nigerian Universities as well as making it COREN registrable is borne out of good intention to put it where it rightly belongs. In this work, previous researches on the relevance of Geomatics Engineering in other engineering practices and the advantages the profession has offered other fields of Engineering due to proper placement were reviewed. Geomatics Engineering has metamorphosed over the years and many countries have taken advantages of this development as a welcome idea and Nigeria cannot be exception. This article also revealed the need for the Council for the Regulation of Engineering in Nigeria (COREN), to urgently incorporate Geomatics Engineering into its structure as a field of engineering practice in Nigeria similar to what is obtainable in other advanced counties. This will help in harnessing the full advantage of the profession in the field of Engineering practices where the knowledge of Geomatics is required.
\end{abstract}

Keywords: COREN, Geomatics Engineering, Technological Advancement, Professional

\subsection{Introduction}

Geomatics a new paradigm comes from the French word "géomatique". (Its roots are "geo" (Earth) and "informatics" (information + automation + "ics") which is the accepted form for the name of sciences). Another description of Geomatics was derived from two words Geodesy + Geoinformatics. In the Latin language, the Geomatics correspond to Geomatica (Adeoye, 2010; Nwilo, 1999; Nwilo et al., 2000), and Russia is called Геоматика (Geomatika). Geomatics Engineering is the application of the knowledge of mathematics and sciences leading to the acquisition, processing (arrangement), and interpretations of ground and spatial data which is used for Engineering designs for the benefit of mankind (Junnilainen, 2006).

Junnilainen, (2006) describes terrestrial surveys with a much older history as being the fundamentals for determining size and shape of the earth, and of establishing country and continent-wide reference Networks. He also noted that in ancient time, the surveyor was called a person who uses geometry and primitive tools such as surveying rope, chain or tape in order to define the cadastral edge. A lot of words have been used in order to express Geomatics engineering from ancient time to today such as Geometrist, Surveyor, Survey Engineer, Geodesist, Photogrammetrist, Cartographer, Geoinformatiker, Geomatician etc. As the parallel to the technological development, surveying and mapping sector has improved itself and adapted to the new phenomena. This phenomenon has been synchronized into military and security architecture for the production of maps used in defense and combat. On a global scale, within the Last two centuries, the most affected engineering due to the revolution in computer and space technology is Geomatics Engineering. This is as a result of the sophistication of real time equipment in data capturing, preserving, analysis and presentation (Junnilainen, 2006). 
Also, Geomatics as a department in Engineering that deals with all kinds of position-dependent measurement, calculation, analysis and visualization studies; has the advantage of sharing processed acquired data for engineering designs in Civil/Structural Engineering, electrical Engineering, Water resources and Environmental Engineering. Spatial information for hydrological and hydraulic designs are also acquired by Geomaticians for the design of hydraulic structures. The first beneficiary of acquired data are the Engineers, hence relocating Geomatics to Engineering is an added advantage to the college of Engineering as it is in most advanced countries. Geomatics Engineering is one of the vast engineering branches that are open to technological developments and best practices in contemporary technology (Cerba, 2012).

Geomatics, as a modern discipline, which integrates acquisition, modeling, analysis, and management of spatially referenced data, i.e. data identified according to their locations; its full advantage can be fully harnessed when it is domiciled in the faculty of Engineering for the purpose of share technical facility and ease of access to acquired data (Junnilainen, 2006).Based on the scientific framework of geodesy, it uses terrestrial, marine, airborne, and satellite-based sensors to acquire spatial and other data. It includes the process of transforming spatially referenced data from different sources into common information systems with well-defined accuracy characteristics (URL-1). Besides, Geomatics like other Engineering disciplines involves intersection of the physical, biological, business and social sciences with respect to mathematical and logical relationships as illuminated Fig 1 (URL-2).

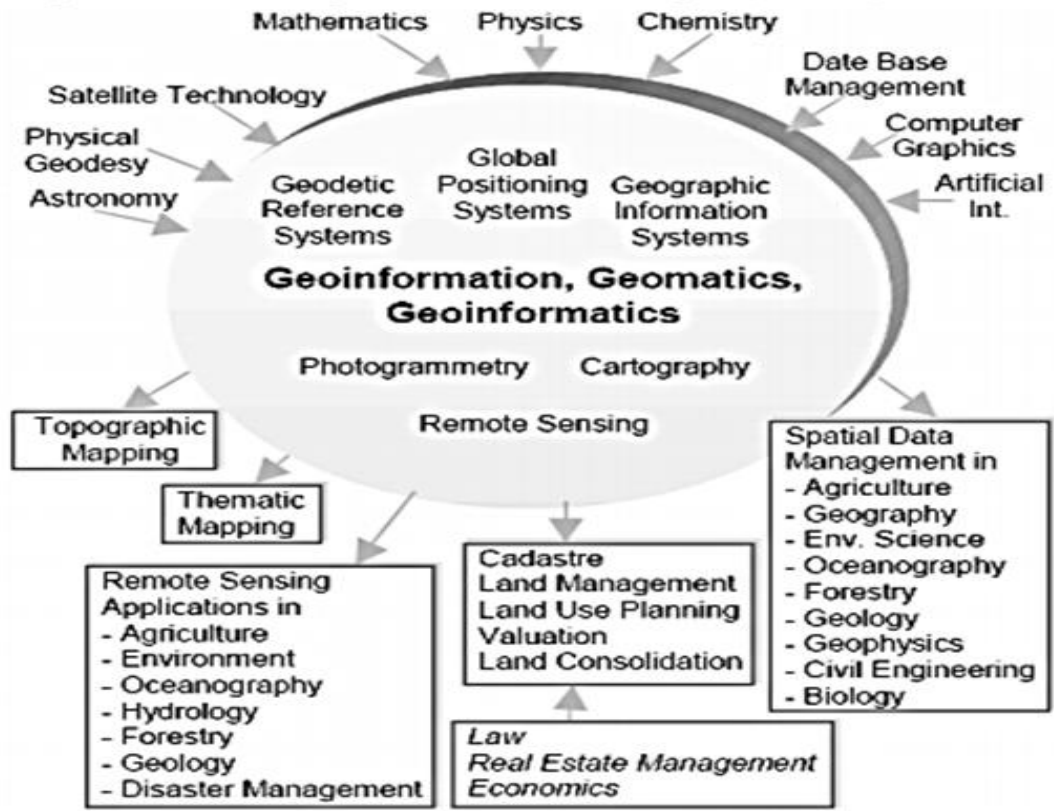

Figure 1: Geomatics at glance. Source: (Grun, 2008)

The aim of geomatics engineering according to Cerba, (2012) involves the development and use of various spatial techniques based on modern technology to better understand, plan, organize, monitor and manage the earth we live in, the production of various maps and spatial data /information for the needs of the country (planning, property, defense etc.) and determining precise position (horizontal and vertical) of any kind of space or land related to the earth. These are the basic details needed for the design of Engineering infrastructure hence to need to bring Geomatics closer to where the outputs are put applied.

\subsection{Aim and Objectives}

The aim of this paper is to unravel the need to teach Geomatics Engineering in Nigerian University, acceptable by Nigerian Society of Engineer (NSE) and to become registrable by Council for the Registration of Engineering in Nigeria (COREN). While the objectives are but not limited to:

a. present the overview of Geomatics engineering at a glance. 
b. showcase the interdependency of major engineering fields with Geomatics Engineering.

c. emphasize the application of Geo-data acquired by Geomatics Engineering to various engineering fields for solving societal problems.

d. disabuse biasness and mediocrity against Geomatics engineering among Nigerians.

\subsection{Justification for the inclusion of Geomatics Engineering in the Faculty of Engineering in Nigerian Universities}

For the past years the polytechnics and universities in Nigeria, have been focused on producing cadastral surveyors and technicians. This was so because of the historical background of the country during the precolonial, colonial and postcolonial eras. The focus was on cadastral and boundary surveying as if it was the only discipline of surveying gave the profession a narrow perception in the eye of the public and making the practicing Surveyor the worse advertiser of their products. Emphasis was more on boundary delineation. The recent advancement in Technology has revolutionized the profession.

Over the last decade the Department of Surveying in most Nigerian University have transformed to the Department of Surveying and Geomatics. In University of Benin, the department was named GEOMATICS in conformity with international standard of nomenclature and because the department is domicile in the Faculty of Environmental Sciences. Most international Universities adopted the name GEOMATICS ENGINEERING or GEOSPATIAL ENGINEERING etc., depending on the Faculty housing the programme. Geomatics at the University of Benin was approved as a department to transform from the traditional surveying programme to one concerned with not just only ground survey data acquisition but also train students in processing the acquired data to produce designs of Engineering infrastructure. Courses in this program covers, highway geometrics, water resources and environmental Engineering, geotechnical engineering and fluid mechanics (Brimicombe, 2008). Increasingly, Geomatics is playing a central role in designing, building and managing the spatial information systems underpinning a modern society. The discipline builds on a strong measurement science base which is closely linked to its traditional land administration focus. The discipline has built on this strategic advantage to focus increasingly on the science, Engineering and management of spatial information.

The introduction of the B.Eng. programme in Geomatics Engineering is justified at this time in Nigeria because in spite of the huge potential for geomatics engineers to provide the needed engineering mapping services for all phases of environmental engineering and management, there are currently few universities offering this programme in Nigeria. The surveying education currently being offered in Nigeria is aimed at practicing as land surveyors and being largely skill and rule based, it does not meet the knowledge-based requirement for Geomatics Technology.

The new geomatics engineer will provide all mapping and engineering surveying services for engineering, scientific and military applications which include: mining and underground engineering works, highway engineering, tunnel engineering, deformation studies, water supply engineering, feasibility studies, erosion modelling \& remediation, flood prediction, refuse evacuation engineering, irrigation \& precision agriculture, navigation and tracking of moving vehicles or objects, Geotechnical Engineering, land surveying for cadastral, mapping for the production of township maps, establishment of geodetic control networks for establishment of national or state plane coordinate systems, establishment of national geodetic datums and linkage with international datums, precise positioning of scientific structures, space exploration, study of earth dynamics, measurements and predictions of earth tremors and quakes, rocket launching, military engineering and intelligence gathering, pipeline engineering, power line engineering, optimal route selection, environmental systems modelling, automated mapping and facilities mapping (AM/FM), contextual analysis of spatial features, etc. (Brimicombe, 2008). The table below show list of some selected leading Universities in the world offering Geomatics Engineering and the equivalent degree certificate compared to B.Eng. certificate issued in Nigerian Universities offering Engineering, accredited and registrable by (COREN). The 
advantages enjoyed by these institutions include; shared facilities, ease of access to acquired data, robust knowledge in data (point and spatial) acquisition and design using the acquired data etc. The Nigerian University Geomatics Engineering graduates also stand the chance of benefiting from the above listed advantages and in addition be acquitted with the type of data details to acquire for specific projects. Table 1 is list of Universities oversea offering Geomatics Engineering.

Table 1: Some Universities offering Geomatics Engineering Programme

\begin{tabular}{|c|c|c|c|c|}
\hline $\mathbf{S} / \mathbf{N}$ & University & Degree Offered & Faculty & Location \\
\hline 1 & $\begin{array}{l}\text { Imperial College of Science, } \\
\text { Technology and Medicine }\end{array}$ & B.Eng. Geomatics Engineering & Engineering & UK \\
\hline 2 & University College, London & B.Eng. Geomatics Engineering & Engineering & UK \\
\hline 3 & $\begin{array}{l}\text { De Montfort University, } \\
\text { Leicester }\end{array}$ & B.Eng. Geomatics Engineering & Engineering & UK \\
\hline 4 & $\begin{array}{l}\text { Moscow State University of } \\
\text { Geodesy and Cartography }\end{array}$ & $\begin{array}{l}\text { M.Sc. Engineering Geodesy } \\
\text { and Geomatics }\end{array}$ & $\begin{array}{l}\text { Engineering and } \\
\text { management }\end{array}$ & $\begin{array}{l}\text { Russia, } \\
\text { Moscow }\end{array}$ \\
\hline 5 & $\begin{array}{l}\text { Siberian State University of } \\
\text { Geosystems and Technology }\end{array}$ & $\begin{array}{l}\text { M.Sc. Geodesy and Geomatics } \\
\text { Engineering }\end{array}$ & Engineering & $\begin{array}{l}\text { Russia, } \\
\text { Novosibirsk }\end{array}$ \\
\hline 6 & University of Melbourne & B.Eng. Geomatics Engineering & Engineering & Australia \\
\hline 7 & $\begin{array}{l}\text { University of New South } \\
\text { Wales (UNSW) }\end{array}$ & B.Eng. Geomatics Engineering & Engineering & Australia \\
\hline 8 & University of Queensland & B.Eng. Geomatics Engineering & Engineering & Australia \\
\hline 9 & $\begin{array}{l}\text { University of South } \\
\text { Australia }\end{array}$ & B.Eng. Geomatics Engineering & Engineering & Australia \\
\hline 10 & Ohio State University & B.Eng. Geomatics Engineering & Engineering & $\begin{array}{l}\text { Columbus, } \\
\text { USA }\end{array}$ \\
\hline 11 & University of Wisconsin & B.Eng. Geomatics Engineering & Engineering & Wisconsin USA \\
\hline 12 & University of Maine & $\begin{array}{l}\text { B.Eng. Spatial Information } \\
\text { Engineering }\end{array}$ & Engineering & Orono, USA \\
\hline 13 & $\begin{array}{l}\text { California State University, } \\
\text { Fresno }\end{array}$ & $\begin{array}{l}\text { B.Eng. Geomatics Engineering } \\
\text { Department }\end{array}$ & Engineering & California \\
\hline 14 & University of Tehran, & $\begin{array}{l}\text { B.Eng. Department of } \\
\text { Surveying and Geomatics } \\
\text { Engineering }\end{array}$ & Engineering. & Iran \\
\hline 15 & $\begin{array}{l}\text { British Columbia Institute of } \\
\text { Technology. }\end{array}$ & $\begin{array}{l}\text { B.Eng. Department of } \\
\text { Geomatics Engineering } \\
\text { Technology. }\end{array}$ & $\begin{array}{l}\text { School of Construction } \\
\text { and the Environment }\end{array}$ & $\begin{array}{l}\text { British } \\
\text { Columbia, } \\
\text { Canada. }\end{array}$ \\
\hline 16 & University of Calgary & B.Eng. Geomatics Engineering & Engineering & Canada \\
\hline 17 & $\begin{array}{l}\text { University of New } \\
\text { Brunswick, Fredericton }\end{array}$ & $\begin{array}{l}\text { B.Eng. Geodesy and Geomatics } \\
\text { Engineering }\end{array}$ & Engineering & Canada \\
\hline 18 & University of Toronto & B.Eng. Geomatics Engineering & Engineering & Canada \\
\hline 19 & $\begin{array}{l}\text { Dublin Institute of } \\
\text { Technology }\end{array}$ & B.Eng. Geospatial Engineering & Engineering & $\begin{array}{l}\text { Republic of } \\
\text { Ireland }\end{array}$ \\
\hline 20 & Purdue University & $\begin{array}{l}\text { B.S. (LSE) and B.S. (LSE \& } \\
\text { BSCE) }\end{array}$ & Engineering & $\begin{array}{l}\text { West - } \\
\text { Lafayette, USA }\end{array}$ \\
\hline 21 & $\begin{array}{l}\text { Kwame Nkrumah University } \\
\text { of Science and Tech. } \\
\text { Kumasi }\end{array}$ & B.Sc. (Geodetic Engineering) & Engineering & Ghana \\
\hline 22 & $\begin{array}{l}\text { University of Mines and } \\
\text { Technology, Tarkwa }\end{array}$ & B.Sc. Geomatics Engineering & $\begin{array}{l}\text { Mineral Resources } \\
\text { Technology }\end{array}$ & Ghana \\
\hline 23 & University of Nairobi & B.Sc. (Geospatial Engineering) & Engineering & Kenya \\
\hline 24 & University of Stuttgart & B.Eng. Geomatics Engineering & Engineering & Germany \\
\hline 25 & University of Twente & M.Sc. Spatial Engineering & $\begin{array}{l}\text { GeoInformation } \\
\text { Science and Earth } \\
\text { Observation (ITC) }\end{array}$ & Netherlands \\
\hline
\end{tabular}

\subsection{Some Equipment Used in Geo-Data Acquisitions in Geomatics}


Some of the equipment used in Geomatics shows that some professionally trained persons can understand and handle them successfully. These devices are used to acquire data which form the basis of Engineering designs. Various data such as: one dimensional, two dimensional, three dimensional, even four dimensional are products from Geomatics engineering work which are needed for various engineering design purposes.
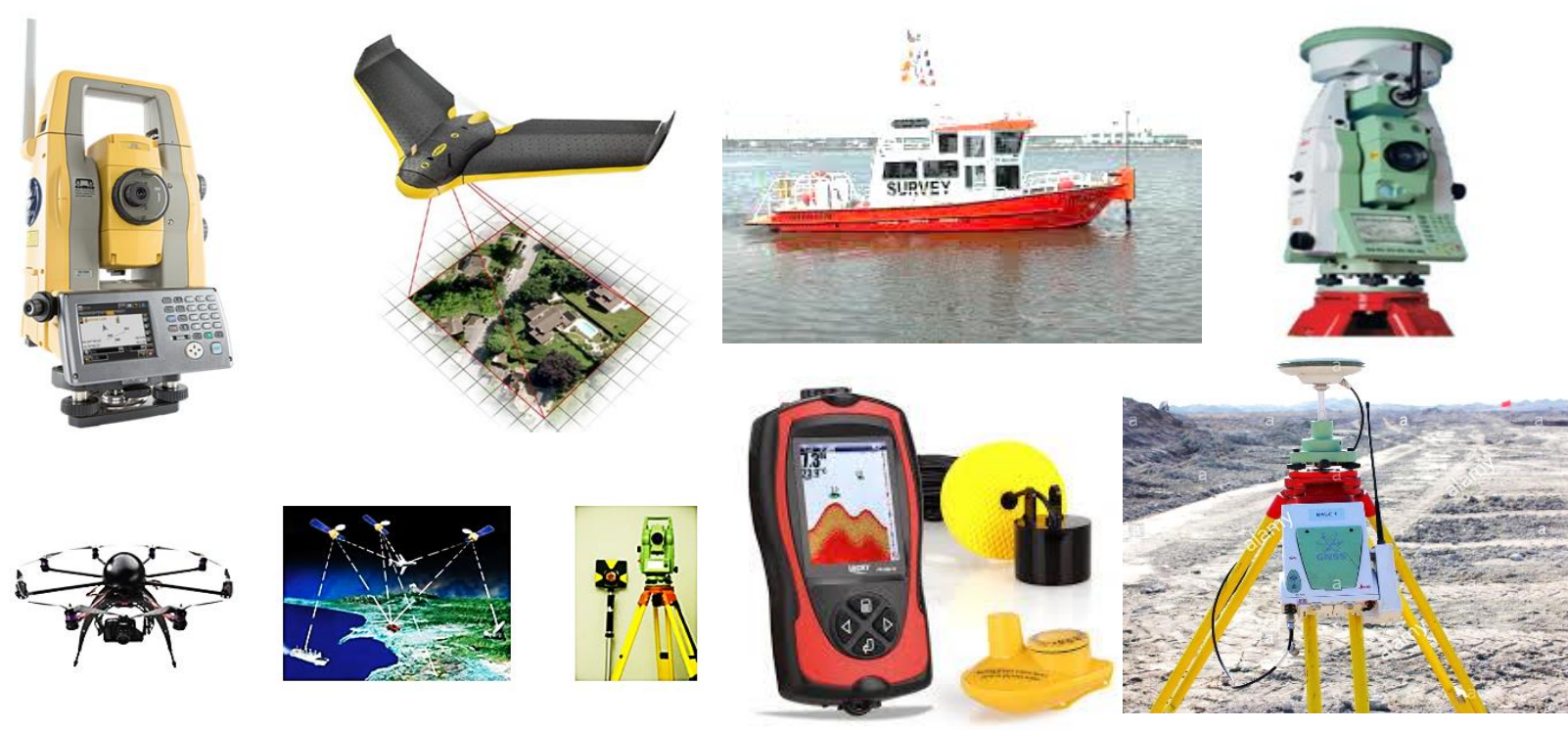

Figure 2: Some modern Geomatics Engineering Equipment

Fajemirokun et al., (2002) affirmed that with the enlarged tasks of surveying, the need for new or modified curricula in the tertiary institutions in Nigeria has become paramount. In view of this, the curriculum of Geomatics department, University of Benin and that of other institutions like University of Lagos have been revisited and review severally as occasion demands by many capable hands to reflect the internationally accepted best practices. Geomatics as identified by most engineering professionals as also the case observed in Nigeria is closely related to the disciplines listed in Table 2.

Table 2: Closely related disciplines to Geomatics Engineering

\begin{tabular}{|c|l|c|l|}
\hline 1 & Computer Science & 9 & Geotechnical Engineering \\
\hline 2 & Information Science & 10 & Metrology \\
\hline 3 & Civil Engineering & 11 & Coastal Engineering \\
\hline 4 & Geophysics & 12 & Disaster/hazard Engineering \\
\hline 5 & Environmental and Natural Resource Management & 13 & Applied mathematics \\
\hline 6 & Instrumentation Engineering & 14 & Space Engineering \\
\hline 7 & Hydrology & 15 & Navigation Engineering \\
\hline 8 & Glaciology and Sea Level & 16 & Railway Engineering \\
\hline
\end{tabular}

As in all disciplines of the engineering profession, Geomatics Engineering is influenced by: Global trends, Regional needs and trends, National needs and trends, State needs and trends as well as Ethical concerns, Social responsibilities and Independence. In Figure 3, Laser scanner and Total station equipment can be seen at glance in industrial application work. Starting from inventory survey to capture and update, the plant inventory as the solid basis for planning and the subsequent creation of plans, factory information systems and 3D models, setting-out and control measurements are carried out during the alterations and new constructions. Post construction surveys, deformation monitoring 
and as-built surveys carried out by Geomaticians have saved a lot of damages to engineering infrastructure in recent times (Kufoniyi, 1999).
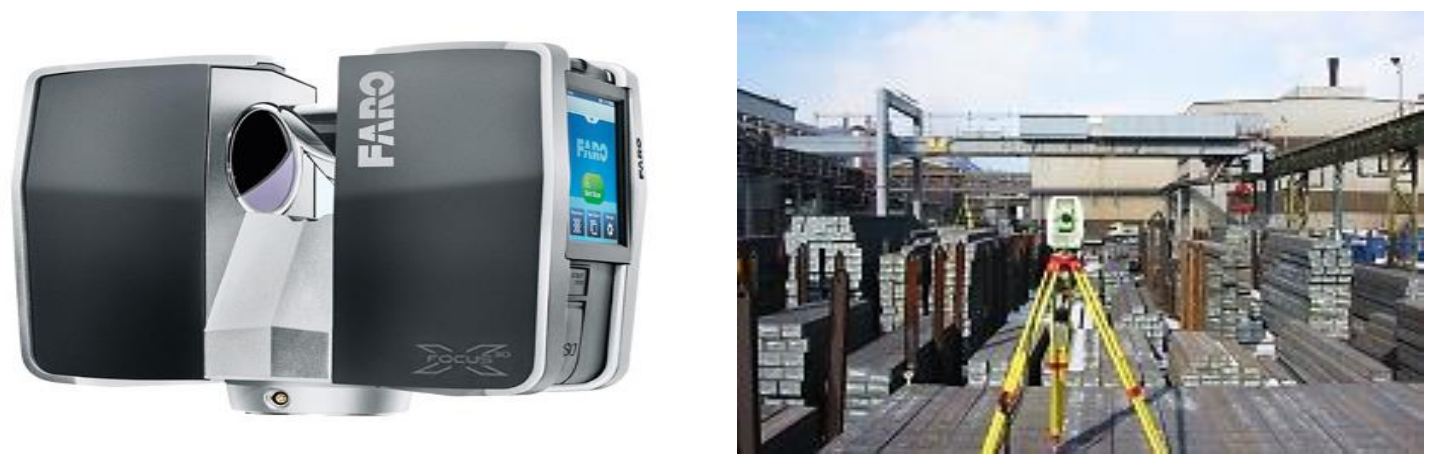

Figure 3: Laser Scanner and Total station in industrial application (Source: GEODATA, 2015).

Thereafter, machines and tools are positioned and accurately aligned and calibrated and inspected to ensure the quality of the finished product as well as all the necessary control and monitoring measurements during ongoing operations; for instance, on crane tracks, rolling mill frames, etc. Measurement data with high precision for accurate information on the size, shape and position of objects on site with pinpoint accuracy using the advantage of the latest technology are now possible Figure 3 shows a total station being used for alignment in an industrial setup (Kufoniyi, 1999).
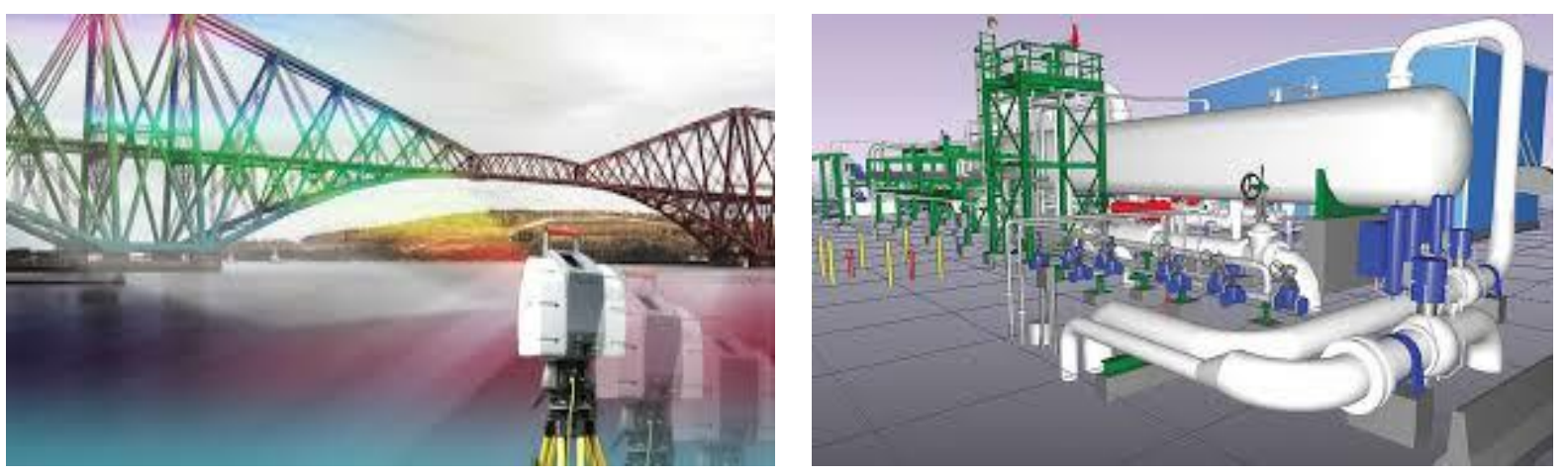

Figure 4: Application of laser scanner on bridge and pipeline (Source: Mills et al., 2004)

\subsection{Geomatics View of Societal Needs}

What the society needs from the perspective of a Geomatics Engineers are specified as follows.

a. The need to have a place to live and work;

b. The need to manage our cities with this being an increasing requirement;

c. The need to manage the land and marine environment which is on the increase;

d. The need to continue to build and increasingly maintain our physical infrastructure.

All these activities are central to the role of a Geomatics Engineer. As a result of the above, there will be increasing needs within society for the management of spatial information (Mills et al., 2004). Specifically, society will require Geomatics Engineers to among other things to engage in the following services.

- Design, build and manage spatial data infrastructures such as the geodetic framework, the various base mapping systems, the new spatial data collection technologies such as highresolution satellites and spatial data measuring systems such as the global positioning system. 
- Society will increasingly need to design, build and manage the spatial business systems concerned with the natural and built environment which build on this spatial data infrastructure. This will include all the systems to manage utilities and services, geographic information systems (GIS), land administration systems and all the natural resource information systems including the marine environment.

- Society will continue to require Geomatics Engineers to design, build and manage the urban and rural habitation which has been a traditional function of survey engineers. This includes the development of residential, commercial and industrial land developments.

- Finally, within this more complex society, Geomatics Engineers will increasingly be required to design and apply the measurement systems which will control much of the construction and management of the above development and management of the environment for the benefits of mankind.

From the list above, it can be concluded that society will have an increasing requirement for an engineering profession which is responsible for ground data acquisition, spatial information acquisition, post construction survey, infrastructure deformation monitoring and managing 3D Geospatial dimensional space of our natural and built environment.

\subsection{Geomatics Engineering Curriculum Design}

The design of curriculum for Geomatics engineering in Nigeria has been advocated by renowned academician and professional stake holders. The training initially offered in the institutions discussed by Fajemirokun, et al., (2002) on Geomatics education in Nigeria was geared towards training in the field of surveying from where students may be exposed to the basic rudiments of computer hardware and software, and taught some of the programming languages. Courses on the various divisions of surveying were offered. Such divisions include Plane Surveying, Engineering Surveying, Geodetic Surveying, Photogrammetry, Remote Sensing and Hydrographic Surveying.

The activities of geomatics are included in, but not limited to, Surveying and Mapping, Cartography, Digital mapping, Geodesy, GIS, Land Information Management, Digital Photogrammetry and Remote Sensing. Geomatics can also be regarded as the integration of the traditional survey techniques and applications with the modern methods of Global Navigation Satellite System (GNSS), Remote Sensing and Geographic Information System Fajemirokun, et al., (2002).

Due to the change of emphasis from Surveying to Geomatics, the training of surveyors in Nigeria is being modified to meet the training needs of geomatics education. Many institutions at the University and Polytechnic levels are now modifying their curricula so as meet the training needs for the geomatics education. It has indeed become very important for every higher institution in the country to change or modify their curricula in order to produce the needed man power to meet the current needs in the private and public sectors.

Many professionals in allied fields like engineering, sciences, health and social sciences and even in education and business administration are now embracing Geomatics. The higher institutions offering surveying are now saddled with the task of developing new curricula to train Geomatics Engineer and professionals from other fields of study (Fajemirokun, et al., 2002). In the light of this, several institutions of higher learning previously offering Geomatics as surveying, or surveying and Geoinformatics have seen need to upgrade to the internationally acceptable best practices of upgrading to full Geomatics training. Table 3, is a sample of the designed curriculum currently being run in the Department of Geomatics, University of Benin (UNIBEN).

Table 3: Sample of curriculum design and courses taken by Geomatics students UNIBEN

\begin{tabular}{|l|l|l|l|}
\hline $\begin{array}{l}\text { COURSE } \\
\text { CODE }\end{array}$ & COURSE TITLE 100 Level & $\begin{array}{l}\text { COURSE } \\
\text { CODE }\end{array}$ & COURSE TITLE 200 Level \\
\hline
\end{tabular}




\begin{tabular}{|c|c|c|c|}
\hline CHM 111 & General Chemistry I & GEM 221 & Introduction to Geomatics Engineering \\
\hline CHM 113 & Organic Chemistry I & EMA 281 & Engineering Mathematics I \\
\hline MTH 111 & Algebra and Trigonometry & GEM 231 & Introduction to Computer Programming \\
\hline MTH 112 & Calculus and Real Analysis & MEE 211 & Applied Mechanics I \\
\hline PHY 111 & Mechanics, Thermal Physics \& Properties of Matter & MEE 221 & Engineering Drawing, I \\
\hline PHY 113 & Vibrations, Waves and Optics & EEE 211 & Electrical Engineering, I \\
\hline GST 111 & Use of English I & GEM 211 & Basic Environmental Geomatics I \\
\hline GST 112 & Philosophy and logic & CVE 211 & Strength of Materials \\
\hline CHM 122 & General Chemistry II & LAB 201 & Laboratory/ Field Work I \\
\hline CHM 124 & Organic Chemistry II & EMA 282 & Engineering Mathematics II \\
\hline MTH 123 & Vectors, Geometry and Statistics & GEM 212 & Basic Environmental Geomatics II \\
\hline MTH 125 & Differential Equation and Dynamics & GEM 232 & Engineering Computer Graphics\& CADD \\
\hline PHY 109 & Practical Physics & GEM 252 & Computer Application to Geomatics Engineering \\
\hline PHY 124 & Electromagnetism \& Modern physics & MEE 212 & Engineering Mechanics II \\
\hline GST 121 & Peace Studies and Conflict Resolution & GEM 222 & Mathematical Cartography \\
\hline GST 122 & Nigerian Peoples and Culture & CVE 212 & Element of Architecture I \\
\hline \multirow[t]{2}{*}{ GST 123} & History and Philosophy of Science & EEE 212 & Electrical Engineering II \\
\hline & 300 Level $1^{\text {st }}$ Semester & LAB 202 & Laboratory/Field Work II \\
\hline EMA 381 & Engineering Mathematics III & & 500 Level $1^{\text {st }}$ Semester \\
\hline MEE 351 & Thermos Dynamics & PRE 571 & Engineering Management, Economics and Administration \\
\hline CVE 341 & Engineering Geology I & GEM 531 & Engineering Geodesy I \\
\hline GEM 331 & Geomatics Engineering Networks & GEM 521 & Space Geodesy \\
\hline GEM 311 & Cadastral and Land Information Management & GEM 531 & Digital Image Processing \\
\hline GEM 341 & Engineering Statistics & GEM 541 & Digital Terrain Model \\
\hline GEM 361 & Geospatial Information System I & GEM 501 & Project \\
\hline GEM 351 & Photogrammetry \& Remote Sensing I & CVE 521 & Civil Engineering Hydraulics \\
\hline MEE 361 & Fluid Mechanics I & GEM 511 & Geo-Environmental Engineering \\
\hline \multirow{2}{*}{ GST 300} & Entrepreneurship & GEM 581 & Lab/ Field work V \\
\hline & 300 Level $2^{\text {nd }}$ Semester & & OPTIONAL COURSES (Choose two Courses only) \\
\hline EMA 382 & Engineering Mathematics IV & GEM 551 & Applied Building Information Modelling \\
\hline GEM 317 & Engineering Geophysics & CVE 523 & Engineering Hydrology I \\
\hline GEM 312 & Operation Research in Engineering & CVE 553 & Non-Topographic Photogrammetry \\
\hline GEM 322 & Hydrology and Water Resources Engineering & CVE 555 & Positioning, Navigation and Wireless location \\
\hline GEM 362 & Photogrammetry and Remote Sensing II & CVE 541 & Geotechnical Engineering \\
\hline GEM 392 & Hydroinformatics Engineering I & & \\
\hline GEM 332 & Mining and Special Geomatics Engineering & & 500 Level 2nd Semester \\
\hline GEM 352 & Geometric Geodesy & GEM 528 & Water Resources and Environmental Engineering \\
\hline GEM 372 & Adjustment and Least Squares & GEM 516 & $\begin{array}{l}\text { Mapping Laws and Code of Professional Practice for Civil } \\
\text { and Geomatics Engineering }\end{array}$ \\
\hline \multirow[t]{2}{*}{ ELA 302} & Swimming/Field Camping & GEM 514 & Marine Geodesy \\
\hline & OPTIONAL COURSES (Choose one Course only) & GEM 522 & Physical Geodesy \\
\hline GEM 342 & Geodetic Astronomical Methods & GEM 532 & Engineering Geodesy II \\
\hline GEM 342 & Engineering Geology & GEM 524 & Adjustment \& Mathematical analysis \\
\hline \multirow[t]{2}{*}{ MEE 362} & Fluid mechanics II & GEM 552 & Health, Safety and Environmental Management system \\
\hline & 400 Level 1st Semester & GEM 502 & Final Year Project \\
\hline EMA 481 & Applied Engineering Mathematics & & OPTIONAL COURSES (Choose two Courses only) \\
\hline CVE 441 & Soil Mechanics & GEM 592 & Sensor Web and Internet of Things \\
\hline GEM 421 & Engineering Surveying & GEM 562 & Environmental Remote Sensing and GIS \\
\hline GEM 461 & Geospatial Information System II & GEM 572 & Environmental modeling \\
\hline GEM 451 & Advanced Remote Sensing and GIS & GEM 556 & Environmental Monitoring and Management \\
\hline GEM 411 & Hydroinformatics Engineering II & CVE 522 & Engineering Hydrology II \\
\hline CVE 423 & Environmental Engineering & & \\
\hline GEM 471 & Potential Theorem and Spherical Harmonic & & \\
\hline GEM431 & Geodetic Engineering & & \\
\hline CVE 431 & Introduction to Transportation Engineering & & \\
\hline \multirow[t]{2}{*}{ LAB 401} & Laboratory/field work IV & & \\
\hline & OPTIONAL COURSES (Choose one Course only) & & \\
\hline CVE 421 & Hydraulic and Hydrology & & \\
\hline \multirow[t]{3}{*}{ CPE 481} & Numerical Computation & & \\
\hline & 400 Level 2ndSemester & & \\
\hline & SIWES (Industrial Training) & & \\
\hline
\end{tabular}

Table 3 reflects the summation of courses offered in the department of Geomatics, university of Benin. The programme contains 53\% Engineering courses covering Civil and Mechanical Engineering; and 47\% Surveying courses. The more than 50\% Engineering courses give the students leverage in Engineering practices and profession. We therefore recommend Table 3 to National University 
Commission (NUC) and COREN as the minimum requirements by students offering Geomatics engineering to pass before graduating from Nigeria Universities. It is a reflection of the evolvement and revolution of the discipline of Geomatics over time and over the world.

\subsection{Conclusion}

Geomatics Engineering in higher education around the world used to be in a perilous condition because of student low turnout and lack of proper awareness of what the programme entails. Recently, this narrative is changing globally as there is a holistic marketing approach in ensuring that the advantages of geomatics engineering is appreciated in nearly all fields of engineering and Nigerian universities cannot be exception. The change in the discipline has been dramatic and exciting and here is a great deal of demand for the graduates and very good support for sponsored-research in the Geomatics Engineering discipline. Therefore, this study has added immensely to the clarion call of geomatics engineers for the inclusion of geomatics into Nigerian Universities curriculum and also a division in Nigeria Society of Engineers which is registrable by the Council for the Regulation of Engineering in Nigeria, COREN.

\section{References}

Adeoye, A.A. (2010). National Geographic Information Systems Policy. Proceedings of the Nigerian Institution of Surveyors 33rd Annual General Meeting and Conference. pp 68-75. Lagos. Nigerian Institution of Surveyors.

Brimicombe, A.J. (2008). The future of Land Surveying Education: Meeting the needs of a Changing Profession. Surveying World, Vol.6 No.4, pp. 23-26.

Cerba, O., Cada, V., Vichrova, M., Jedlicka, K., Janecka, K., Silhavy, J. and Jezek, J. (2012). Cartographic Education in Geomatics Curriculum, Proceedings - AutoCarto 2012 - Columbus, Ohio, USA

Fajemirokun F. A., Nwilo P. C. and Badejo O. T. (2002). Different Aspects in Planning and Implementing Curricula. Geomatics Education in Nigeria FIG XXII International Congress Washington, D.C. USA.

Grun, A. (2008). Geomatic Engineering and Environmental Engineering. Geomatics Information Magazine (GIM). Vol. 12, pp 30-33.

Junnilainen E. A. (2006). Initiative for International Master Program in Photogrammetry at the Helsinki University of Technology. Shaping the change. XXIII FIG Congress. Munich, Germany

Kufoniyi, O. (1999). Educational Requirements in Geospatial Information Technology. In C.U. Ezeigbo, O. O. Ayeni, F. A. Fajemirokun \& P.C. Nwilo (eds.) Proceedings of the workshop on Surveying and Spatial Information Technology (SSIT): Issues of Name, Concept and Function. pp 5261. Akoka-Lagos. Department of Surveying and Geoinformatics, University of Lagos.

Mills, J. P, Parker, D., Edwards, S. J., (2004). Geomatics.org.uk: A UK response to a global awareness problem. In: International Archives of the Photogrammetry, Remote Sensing and Spatial Information Sciences, 35(B6): 1-6.

Nwilo, P. C. (1999). Training of Surveyors in Nigeria: Future Directions. In C.U. Ezeigbo, O. O. Ayeni, F. A. Fajemirokun \& P.C. Nwilo (eds.) Proceedings of the workshop on Surveying and Spatial Information Technology (SSIT): Issues of Name, Concept and Function. pp 78-85. Akoka-Lagos. Department of Surveying and Geoinformatics, University of Lagos. 
Nwilo, P.C., Peters K.O. \& Badejo, O.T. (2000). New Training Mandates for Surveying and Geoinformatics Institutions in Nigeria. International Archives of Photogrammetry and Remote Sensing. Vol. XXXIII, Part B6. pp 223-230. 